\title{
Thermal analysis of the products of alkali activation of fly ash from CFB boilers
}

\author{
Agnieszka Grela' ${ }^{1}$ Michał $\operatorname{Lach}^{2} \cdot$ Janusz Mikuła $^{2} \cdot$ Marek Hebda $^{2}$
}

Received: 9 September 2015/Accepted: 14 January 2016/Published online: 8 February 2016

(C) The Author(s) 2016. This article is published with open access at Springerlink.com

\begin{abstract}
Currently, in the energy sector circulating fluidized bed boilers are popularly used, resulting in the production of large amounts of fly ash. Due to the limited possibilities of utilization, the development of technology for their processing is crucial. One of the most promising and intensively studied ways to exploit fly ash (including those derived from fluidized bed boilers) is their use for the synthesis of zeolite materials. Here, we present the methods of manufacturing zeolite materials from fly ash obtained from hard coal combustion in circulating fluidized bed (CFB) boilers. The paper details the characteristics of the substrates [fly ash from two different combined heat and power (CHP) plants] and products of synthesis conducted according to two methods-the low-temperature method and the fusion method. Both the substrates and the products of each particular synthesis were subjected to thorough examination in terms of density, morphology, phase composition, specific surface area and the average diameter and volume of pores. Conducting thermal analysis combined with quadruple mass spectrometry enabled the interpretation of the physicochemical process occurring during heating and the determination of the thermal stability of the examined materials. Zeolite $\mathrm{X}$ was obtained via low-temperature synthesis of fly ash from the CFB boiler of one of the CHP plants. According to the examination,
\end{abstract}

Marek Hebda

mhebda@pk.edu.pl

1 Institute of Water Engineering and Management, Cracow University of Technology, Warszawska 24, 31-155 Kraków, Poland

2 Institute of Materials Engineering, Cracow University of Technology, Warszawska 24, 31-155 Kraków, Poland the presence of $\mathrm{Ca}$ in fly ash seriously hinders zeolite synthesis.

Keywords CFB-coal fly ash · Zeolite synthesis · Thermal analysis

\section{Introduction}

In the energy sector, circulating fluidized bed (CFB) boilers began to be used in the 1990s. This resulted in an increase in the amount of fly ash from power plants burning coal on CFB beds (e.g., in Poland from approximately 750,000 tons in 1998 to approximately $2,000,000$ tons in 2015) [1]. Therefore, the need for new methods for its disposal has become urgent. At first sight, such wastes may be easily exploited in various branches of the industry. However, few applications have been successfully implemented because the combustion temperature in CFB boilers does not exceed $900{ }^{\circ} \mathrm{C}$ and the material does not undergo melting. Consequently, grains in the obtained ash have an irregular shape and contain a large amount of crystalline particles, which is undesirable for the construction industry [2].

Nevertheless, year on year increasing amounts of fly ash derived from coal combustion in CFB boilers have been reused. In terms of the entire European Union, while in $200367 \%$ of this ash became a substrate for industry, in 2010 up to $81 \%$ was reused. In the EU, this ash is mainly applied in site remediation, as an additive to cements (bottom ash), as a fire-quenching medium or as a road foundation [1]. In the USA, it is mainly used in road and embankment construction and for ground stabilization [3]. Currently, the most promising and extensive research is conducted on turning fly ash, including ash from coal 
combustion in CFB boilers, into zeolite materials. Manufacturing such materials is expected to bring particularly good results in terms of the economy and ecology, as among all by-products of combustion the proportion of CFB boiler waste is increasing. Zeolite materials typically have a density of $2.1-2.3\left(\mathrm{~g} \mathrm{~cm}^{-3}\right)$, specific surface area of 200-900 $\mathrm{m}^{2} \mathrm{~g}^{-1}$, ion exchange ability of $150-700 \mathrm{meq} /$ $100 \mathrm{~g}$ and water adsorption ability of up to 25 mass\% [4, 5].

Nowadays, under laboratory conditions more than 100 types of zeolite materials might be manufactured. Typically, these are obtained by using heating aluminosilicate substrates in the presence of alkaline solutions (for several hours or days, dependent on the particular raw material and on the applied conditions, such as the temperature range or the type and concentration of the activator). The structure of the obtained zeolite material depends largely on the composition of the initial mixture, namely on the concentrations and quantitative ratios of the components. However, the conditions under which the synthesis is conducted are equally important. These include, for instance, $\mathrm{pH}$ of the solution, applied temperature, time of processing, fineness of the reagents or the decision as to whether to mix them before the activation or not (this influences the crystallization in the chemically identical mixtures) [6].

In zeolite synthesis, various carriers of silica are used. Some are natural (e.g., kaolinite [7] or volcanic glazes [8]), and some are derived from wastes, for example conventional fly ash [9] and fly ash of CFB boiler [10]. Currently, research on zeolite synthesis is focused mainly on its environmental impact, which reflects the need for manufacturing such materials from industrial wastes [11-13].

According to the most recent research, fly ash from hard coal combustion in CFB boilers may be turned into zeolite materials using hydrothermal activation [14-16].

This paper presents the results of the alkali activation of fly ash from hard coal combustion in CFB boilers. As two methods of synthesis were employed (fusion method and low-temperature method), the examination was focused on the influence of the particular method of synthesis on the characteristics of the obtained materials, such as density, chemical composition, thermal stability, specific surface area and size and volume of pores. The research should contribute to the creation of a recipe for zeolite materials.
The results will in the future allow the correct choice of synthesis parameters for zeolite materials. Fly ash from fluidized bed boilers can be used as substrates for cheaper low-grade synthetic sorbents with broad applications.

\section{Materials and methods}

\section{Characteristics of the raw materials}

Fly ash from two separate CHP plants (the second largest electricity supplier in Poland), namely from CHP plant A (PP.AB) and CHP plant B (PP.BB), was subjected to tests. In both cases, fly ash was derived from hard coal combustion in CFB boilers. The composition of the oxide of samples was determined using the methods of classical (mass- $\mathrm{SiO}_{2}, \mathrm{SO}_{3}$; titration- $\mathrm{Al}_{2} \mathrm{O}_{3}, \mathrm{Fe}_{2} \mathrm{O}_{3}, \mathrm{CaO}, \mathrm{MgO}$ ) and instrumental analysis (spectrophotometry). Each of the methods involved the use of a separate method for converting the samples into solution. The content of the particular oxides in the examined raw materials is presented in Table 1. The ashes differ from each other in terms of both chemical composition and mineralogy. These parameters are crucial in the synthesis of zeolites. Therefore, it was decided to use two different ashes with different $\mathrm{CaO}$ levels (approximately $60 \%$ ). Table 2 presents data concerning the fuel and the technological chain from which the ash samples were derived [17].

\section{Method of synthesis}

There are four common methods for the synthesis of zeolite materials from waste materials [18]. We chose two of them: fusion synthesis (Fig. 1a) and low-temperature synthesis (Fig. 1b). They differ in respect of the applied time, temperature and concentration of the activator $(\mathrm{NaOH})$.

\section{Fusion method}

A certain amount of raw materials (RM) - fly ash from coal combustion in CFB boilers and the activator (technical $\mathrm{NaOH}$ whose purity $>98 \%$ ) - was mixed in a fire-resistant

Table 1 Content of oxides in the fly ash from coal combustion in CFB boilers

\begin{tabular}{|c|c|c|c|c|c|c|c|c|c|c|}
\hline \multirow{2}{*}{$\begin{array}{l}\text { Labeling of the samples } \\
\text { of raw materials (fly ash) }\end{array}$} & \multicolumn{10}{|c|}{ Content of oxides $/ \%$} \\
\hline & $\mathrm{SiO}_{2}$ & $\mathrm{Al}_{2} \mathrm{O}_{3}$ & $\mathrm{Fe}_{2} \mathrm{O}_{3}$ & $\mathrm{Na}_{2} \mathrm{O}$ & $\mathrm{K}_{2} \mathrm{O}$ & $\mathrm{CaO}$ & $\mathrm{MgO}$ & $\mathrm{TiO}_{2}$ & $\mathrm{SO}_{3}$ & Reactive silica \\
\hline PP.AB & 39.7 & 19.6 & 8.4 & 2.66 & 2.19 & 12.2 & 2.1 & 0.9 & 5.82 & 27.1 \\
\hline PP.BB & 37.4 & 17.4 & 5.9 & 1.07 & 2.44 & 19.7 & 1.8 & 0.8 & 6.47 & 24.3 \\
\hline
\end{tabular}

PP.AB — fly ash from CHP plant A, PP.BB-fly ash from CHP plant B 
Table 2 Determination of the samples and the description of the technological chain which leads to obtaining the examined samples of fly ashes

\begin{tabular}{lllll}
\hline Sample symbol & $\begin{array}{l}\text { Main fuel } \\
\text { Type }\end{array}$ & Power boilers & $\begin{array}{l}\text { Flue gas dedusting } \\
\text { system/filters }\end{array}$ & $\begin{array}{l}\text { The amount of fly ash } \\
\text { produced (1000 tons/year) }\end{array}$ \\
\hline PP.AB & Hard coal & CFB boiler type OFz-425/t/h & Electrofilters & 75 \\
PP.BB & Hard coal & CFB boiler type CFB-260/t/h & Electrofilters & 45 \\
\hline
\end{tabular}

${ }^{a}$ Data from 2005 year [17]

Fig. 1 Zeolite synthesis chart a fusion method (F), b low-temperature method (L) (a)

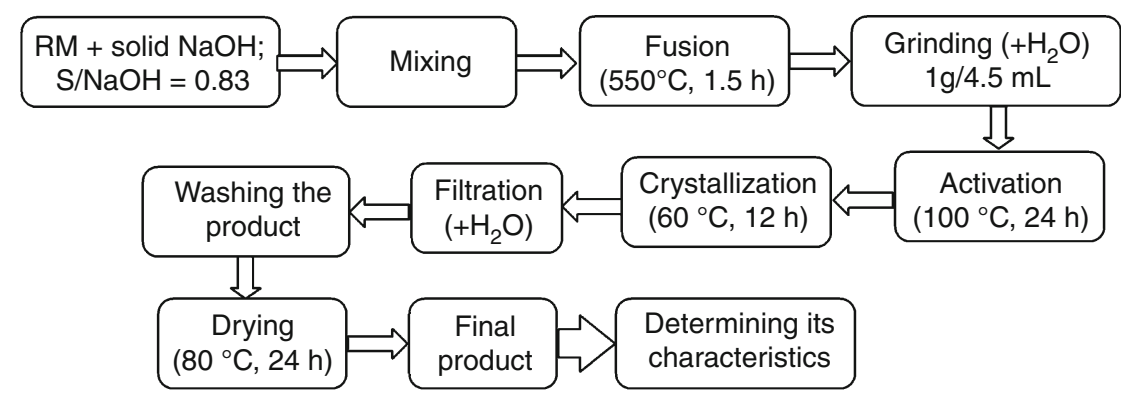

(b)

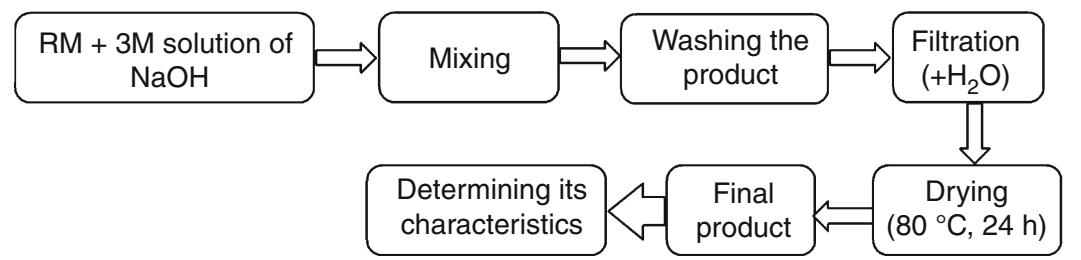

Table 3 Labels of fly ash from coal combustion in CFB boilers in CHP plant A and CHP plant B (before and after the fusion and lowtemperature synthesis)

\begin{tabular}{ll}
\hline $\begin{array}{l}\text { Labels of the } \\
\text { samples }\end{array}$ & $\begin{array}{l}\text { Description } \\
\text { PP.AB }\end{array}$ \\
PP.AL & $\begin{array}{c}\text { Fly ash from the CFB boiler from CHP plant A- } \\
\text { raw material } \\
\text { The material obtained from PP.AB by using the } \\
\text { low-temperature method } \\
\text { The material obtained from PP.AB by using the } \\
\text { fusion method }\end{array}$ \\
PP.AF & $\begin{array}{l}\text { Fly ash from the CFB boiler from CHP plant B- } \\
\text { raw material } \\
\text { PP.BB }\end{array}$ \\
PP.BL material obtained from PP.BB by using the \\
low-temperature method \\
PP.BF
\end{tabular}

crucible (capacity $0.1 \mathrm{dm}^{3}$ ). The ratio of $\mathrm{S} / \mathrm{NaOH}$ was 0.83 . Then, the mixture was sintered for $4 \mathrm{~h}$ at $550{ }^{\circ} \mathrm{C}$ in a muffle furnace. The obtained material was milled and transferred to a glass cylindrical vessel (capacity $1 \mathrm{dm}^{3}$ ). Then, water was added $(4.5 \mathrm{~mL}$ per $1 \mathrm{~g}$ of the sintered material) and the content of the vessel was mixed for $1 \mathrm{~h}$ using an ultrasound. The vessel was put in a laboratory dryer for $24 \mathrm{~h}$ at $100{ }^{\circ} \mathrm{C}$ (activation) and then for $24 \mathrm{~h}$ at $60{ }^{\circ} \mathrm{C}$ (crystallization). After the synthesis, all samples were cooled to room temperature and filtered in order to remove the remnants of the solution used for the activation. Then, the samples were washed with distilled water to obtain pH ca. 10. Finally, the samples were dried at $105^{\circ} \mathrm{C}$ for $6 \mathrm{~h}$.

\section{Low-temperature synthesis}

A certain amount of raw material (RM) - fly ash from coal combustion in CFB boilers-was mixed with a $3 \mathrm{M}$ water solution of $\mathrm{NaOH}$ (purity $>98 \%$ ). The applied ratio was $0.1 \mathrm{dm}^{3}$ of $3 \mathrm{M}$ solution of $\mathrm{NaOH}$ per $10 \mathrm{~g}$ of raw material. The mixture was transferred into $1 \mathrm{dm}^{3}$ polypropylene cylindrical vessels. The vessels were tightly closed and left for 30 days at room temperature $\left(21^{\circ} \mathrm{C}\right)$. The solutions were mixed and shaken every day. After the synthesis, they were filtered to remove the remnants of the solution and then washed with distilled water to obtain $\mathrm{pH}$ ca. 10. The filtration and washing were conducted with filter paper designed for qualitative analysis; it was made of pure cellulose and cotton linters (its filtration time $=10 \mathrm{~s}$ ). Finally, the samples were dried at $105^{\circ} \mathrm{C}$ for $6 \mathrm{~h}$.

The selected methods for synthesis of zeolites are already known. An innovative aspect of this work is to 
carry out the synthesis of the fly ash from fluidized bed boilers. To date, other authors have investigated the possibility of the synthesis of zeolite from the fly ash, but not from fluidized bed boilers. The conducted research was intended to analyze the process of zeolite synthesis from fly ash from the fluidized bed boilers. As the main assumption of the research was to conduct the above-mentioned synthesis as cheaply as possible, low-temperature synthesis was applied, as this should be carried out at room temperature and therefore its costs are greatly reduced in comparison with other methods. Room temperature is often too low for the zeolite to crystallize, but according to the literature zeolites have already been obtained in this way [19-22]. However, in contrast to the low-temperature method, the fusion method caused fly ash originating from the fluidized bed boiler and $\mathrm{NaOH}$ to react with each other in solid form. Information can be found in the literature, stating that the fusion method is the appropriate method for synthesis of zeolite $\mathrm{Na}-\mathrm{X}$.

Table 3 presents the materials obtained by means of the above-mentioned methods of zeolite synthesis and their labels.

\section{Methods of examination}

The samples were appropriately prepared for the examination with a scanning microscope. Small amounts of raw materials and of the obtained products were dried to
Fig. 2 XRD diffractogram of fly ash labeled PP.AB and PP.BB
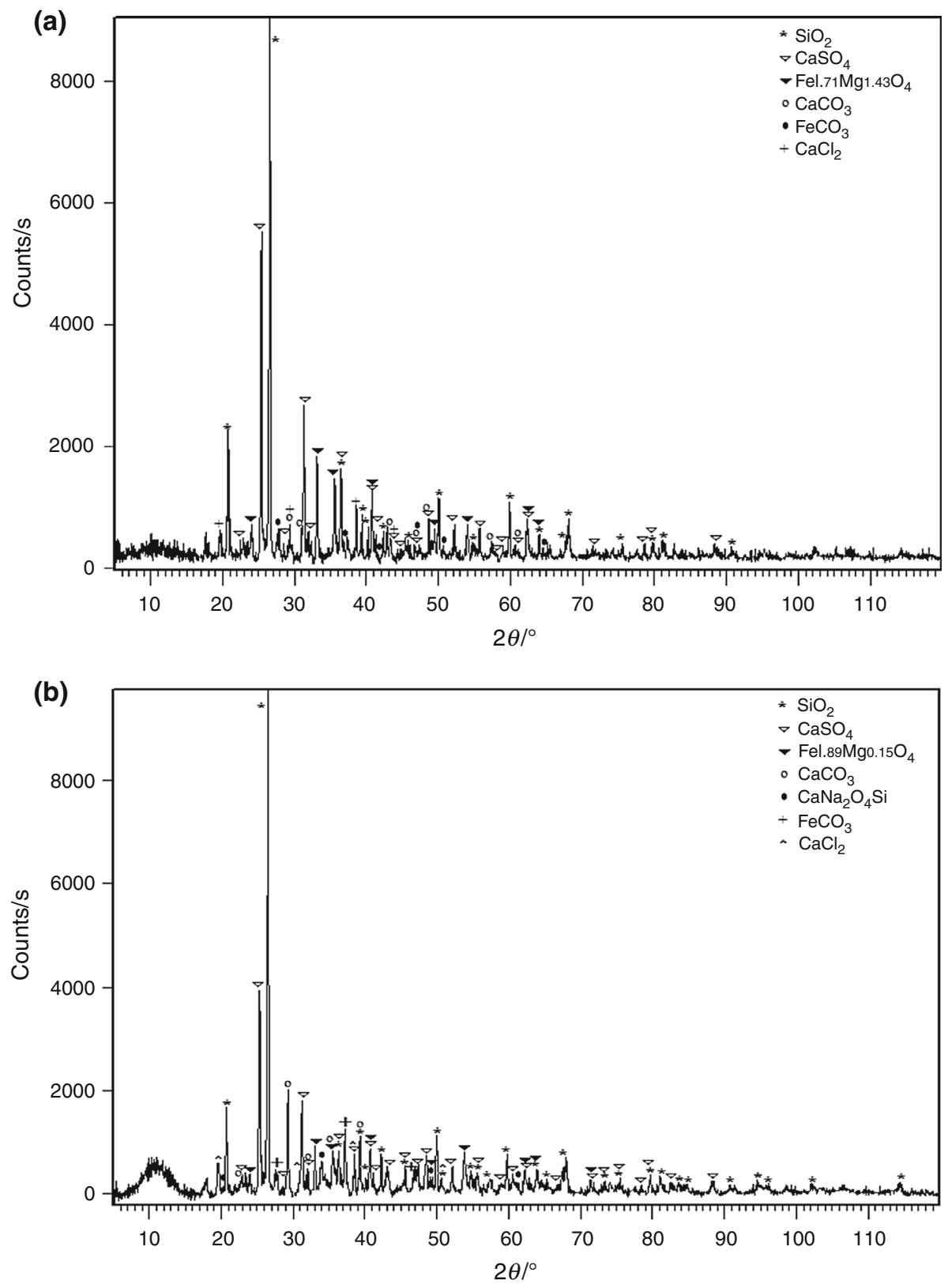
Table 4 Phases identified in the examined raw materials: PP.AB and PP.BB

\begin{tabular}{|c|c|c|c|c|c|}
\hline Ref. code & Chemical name & Chemical formula & Crystal system & PP.AB & PP.BB \\
\hline 01-089-8936 & Silicone oxide & $\mathrm{SiO}_{2}$ & $\begin{array}{l}\text { Hexagonal } \\
a=4.9297 \\
c=5.4151\end{array}$ & + & + \\
\hline $98-001-6382$ & Calcium sulfate & $\mathrm{CaSO}_{4}$ & $\begin{array}{l}\text { Orthorhombic } \\
\begin{array}{l}a=6.9980 \\
b=6.2450 \\
c=7.0060\end{array}\end{array}$ & + & + \\
\hline $00-001-0338$ & Calcium chloride & $\mathrm{CaCl}_{2}$ & $\begin{array}{l}\text { Orthorhombic } \\
\begin{array}{l}a=6.2500 \\
b=6.4400 \\
c=4.2100\end{array}\end{array}$ & + & + \\
\hline $00-056-0629$ & Calcium magnesium iron oxide & $\mathrm{CaMg}_{2} \mathrm{Fe}_{16} \mathrm{O}_{27}$ & $\begin{array}{l}\text { Hexagonal } \\
a=5.8500 \\
c=33.1560\end{array}$ & + & - \\
\hline $98-005-1171$ & Iron-magnesium oxide & $\mathrm{Fe}_{1.8966} \mathrm{Mg}_{0.1551} \mathrm{O}_{3}$ & $\begin{array}{l}\text { Hexagonal } \\
a=5.0490, \\
c=13.7890\end{array}$ & + & + \\
\hline $01-080-2682$ & Iron carbonate & $\mathrm{FeCO}_{3}$ & $\begin{array}{l}\text { Rhombohedral } \\
a=4.3450 \\
c=12.4830\end{array}$ & + & + \\
\hline 98-016-4935 & Calcium carbonate & $\mathrm{CaCO}_{3}$ & $\begin{array}{l}\text { Hexagonal } \\
a=5.0000 \\
c=17.0950\end{array}$ & - & + \\
\hline
\end{tabular}

constant mass and then placed on a coal base to discharge samples. They were also covered with a thin layer of gold with a JEOL JEE-4X vacuum evaporator. The morphology and chemical composition were determined with a JEOL JSM-820 scanning electron microscope via X-ray energydispersive spectroscopy (EDS). The density of the materials was determined with a Pycnomatic ATC helium pycnometer (we used helium 5.0). The porosimetric examination was conducted with an ASAP 2020 sorption analyzer (Micrometrics Company). The specific surface area and the average pore diameter were determined with the BET (Brunauer-Emmett-Teller) method of multilayered adsorption. The pore volume was determined with the BJH (Barrett, Joyner, Halenda) method, whereas the micropore area was ascertained via $t$ plot calculations.

Thermal measurements were taken with STA 409 CD (Netzsch Company) advanced coupling techniques (DSC/ TG) including evolved gas analysis with quadrupole mass spectrometry (QMS 403/5 SKIMMER). The temperature range was from 30 to $900{ }^{\circ} \mathrm{C}$ at a heating rate of $10{ }^{\circ} \mathrm{C} \mathrm{min}{ }^{-1}$. The on-line gas analysis (distance between the sample and QMS was $<20 \mathrm{~mm}$ ) was studied using QMS with an electron ionization source. The spectrometer was operated in multiple ion detection (MID) mode. Air was used as a carrier gas at a flow rate of $80 \mathrm{~mL} \mathrm{~min}^{-1}$. The apparatus was calibrated in accordance with methodology presented in $[23,24]$. The TG/QMS data were analyzed using Proteus software (version 5.2.0) from Netzsch. All the presented curves were corrected against empty runs [25].

The mineral composition of the raw materials and the obtained products was examined via the XRD powder diffraction method with a PANalytical Empyrean XRD diffractometer [anode: copper $(\mathrm{Cu})$, step size $0.026^{\circ}, 300 \mathrm{~s}$ per step]. The obtained products of synthesis were examined with a Rigaku SmartLab XRD diffractometer [anode: copper $(\mathrm{Cu})$, step size $0.050^{\circ}, 1 \mathrm{~s}$ per step]. The small samples of raw materials and obtained products were taken in such a way that each of them was representative. Then, they were dry-pressed, without additional binding material, in a flat vessel made of an X-ray amorphous substance (quartz glass). Such samples were examined with the X-ray diffractometer. The main phases were identified by using the measurement of interplanar distances and the subsequent comparison of the obtained set of data with the pattern set. Diffraction data processing was performed with XRayan version 4.2.1. The mineral phases were identified with a PDF-4+ 2014 database formalized by JCPDSICDD. 

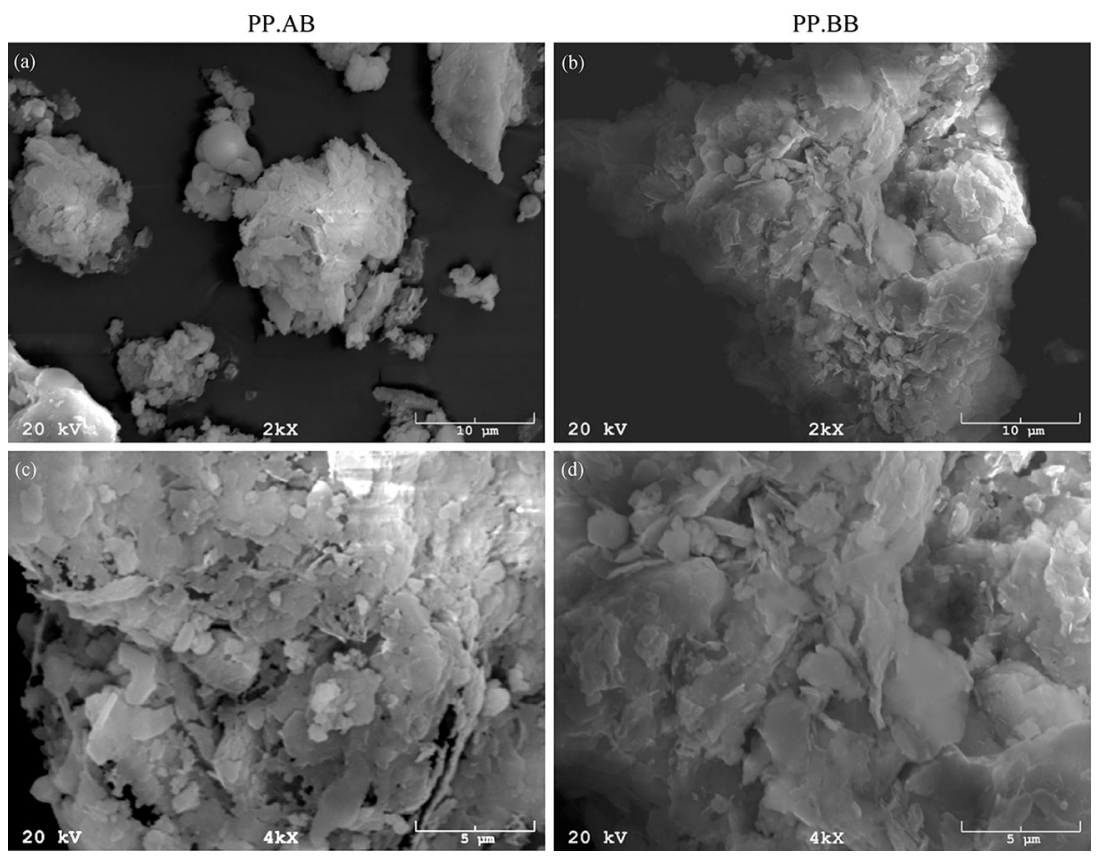

Fig. 3 Morphology of the particles of fly ash from a CFB boiler-sample PP.AB (a, c) and PP.BB (b, d)

\section{Results and discussion}

For both the materials used in the investigation (PP.AB and PP.BB), a high content of sulfuric anhydride was detected (Tables 1,2). This effect is probably the result of the combustion process in fluidized bed boilers conducted in parallel with flue gas desulphurization, during which the following are mainly used as sorbents: chalk, dolomite and limestone.

The following chemical equations demonstrate how the sulfur compounds are chemically bound in this process:

$$
\begin{aligned}
& \mathrm{CaCO} \rightarrow \mathrm{CaO}+\mathrm{CO} \\
& \mathrm{S}+\mathrm{O} \rightarrow \mathrm{SO} \\
& \mathrm{SO}_{2}+\frac{1}{2} \mathrm{O}_{2} \rightarrow \mathrm{SO}_{3} \\
& \mathrm{CaO}+\mathrm{SO}_{3} \rightarrow \mathrm{CaSO}_{4}
\end{aligned}
$$

In order to desulfurize the waste material to a desired level, one must use overabundant quantities of limestone, because only about $30 \%$ of it undergoes the reaction. As a result, waste material contains not only fly ash but also many products of desulfurization, for example anhydrite $\left(\mathrm{CaSO}_{4}\right)$ and unreacted sorbent [26].

Both samples (PP.AB and PP.BB) contained large quantities of $\mathrm{SiO}_{2}$ and $\mathrm{Al}_{2} \mathrm{O}_{3}$, and there was hardly any difference between the samples in terms of the content of those oxides. Therefore, they may be easily turned into zeolites [27]. However, the content of $\mathrm{CaO}$ in both samples varied significantly (in PP.AB it amounted to $12.2 \%$, whereas in PP.BB it amounted to $19.7 \%$ ) which should be stressed, because the presence of calcium compounds generally hinders the process of zeolite synthesis [28, 29]. One of the most important factors influencing zeolite synthesis from fly ash is also the chemical composition of the latter, particularly its silicon oxide and aluminum oxide content ratio. According to the research by Inada et al. [30], one can obtain zeolite Na-P1 of high CEC value from raw material rich in silica (high $\mathrm{Si} / \mathrm{Al}$ ratio). According to some other research, at a $\mathrm{Si} / \mathrm{Al}$ ratio $=2$ hydrothermal synthesis allows A-type zeolite to be obtained. The $\mathrm{Si} / \mathrm{Al}$ ratio $=2.5$ allows nepheline and sodalite to be obtained, but at a $\mathrm{Si} / \mathrm{Al}$ ratio $=3$ or 4 the obtained product is mainly sodalite [31]. In the literature, one can find various zeolites resulting from the synthesis of fly ash at a similar $\mathrm{Si} / \mathrm{Al}$ ratio, because this process is influenced by, among others, the concentration of the specific alkali, applied temperature or crystallization time [31]. In PP.AB and PP.BB, the $\mathrm{SiO}_{2} /$ $\mathrm{Al}_{2} \mathrm{O}_{3}$ ratio is similar, 2.15 for the PP.BB sample, which is slightly higher than for the PP.AB sample $(=2.03)$.

Because the chemical composition of both raw materials is very similar, the process of zeolite synthesis may be influenced by their specific phase composition. In order to determine this, samples PP.AB and PP.BB were subjected to XRD examination (Fig. 2), according to which the main phases of the examined ash were $\mathrm{SiO}_{2}, \mathrm{CaSO}_{4}, \mathrm{CaCl}_{2}$ and $\mathrm{FeCO}_{3}$. A list of these substances is presented in Table 4. On the basis of Table 4, it can be concluded that the identified phases are the results of the technology of combustion in the fluidized bed boiler. The products of flue 

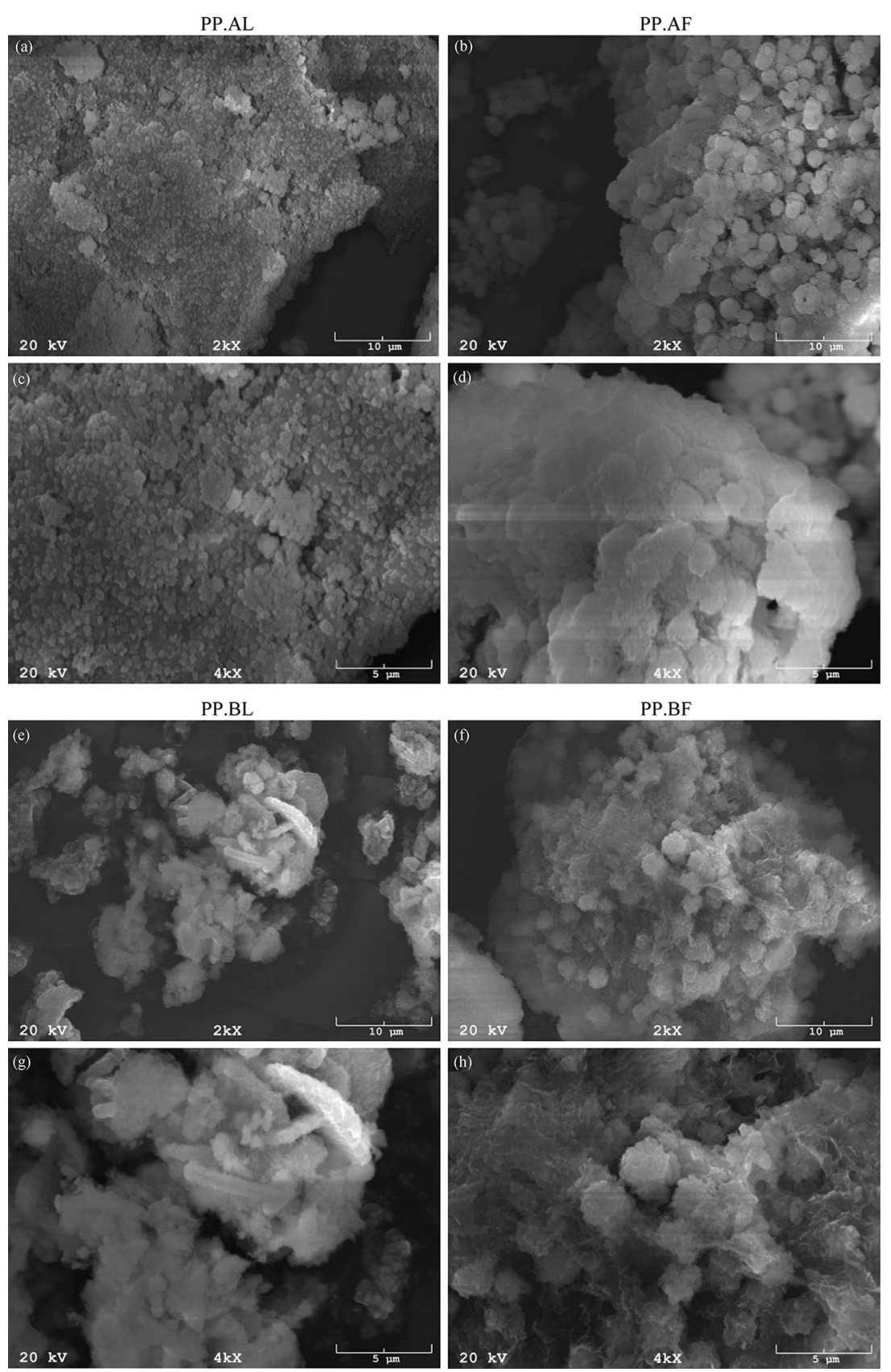

Fig. 4 Morphology of the products of alkali activation of CFB boiler ash from: CHP plant A conducted by using low-temperature method PP.AL $(\mathbf{a}, \mathbf{c})$ and fusion method PP.AF (b, d) and CHP plant B conducted by using low-temperature method PP.BL (e, g) and fusion method PP.BF (f, h)

gas desulfurization $\left(\mathrm{CaSO}_{4}\right)$ as well as significant amounts of silicate minerals and minerals containing $\mathrm{Fe}$ were detected. The analysis did not detect mullite, which is characteristic for conventional ash. Moreover, the difference between the samples lays in the presence of $\mathrm{CaCO}_{3}$ and $\mathrm{CaMg}_{2} \mathrm{Fe}_{16} \mathrm{O}_{27}$ (which, as was explained before, is a key factor influencing the intensity and efficacy of the process of zeolite synthesis and therefore one should expect the PP.AB sample to undergo zeolite synthesis more effectively than sample PP.BB).

Figure 3 presents the morphology of the raw materials. They contained clearly visible grains of $5-20 \mu \mathrm{m}$ in diameter which were compact packages of smaller platelike or leaf-like particles whose dimensions were about 2-5 $\mu \mathrm{m}$. Glued together, they made up larger grains which often had sharp and jagged edges and were hardly ever 
Table 5 Density of the raw materials and of the products of their alkali activation (low-temperature and fusion synthesis)

\begin{tabular}{ll}
\hline Sample labeling & Density/g cm \\
\hline PP.AB & $2.601 \pm 0.003$ \\
PP.AL & $2.365 \pm 0.005$ \\
PP.AF & $2.514 \pm 0.005$ \\
PP.BB & $2.623 \pm 0.005$ \\
PP.BL & $2.476 \pm 0.004$ \\
PP.BF & $2.445 \pm 0.006$ \\
\hline
\end{tabular}

Table 6 Characteristics of the porous structure of the raw materials and the products of their synthesis

\begin{tabular}{lclrr}
\hline Sample labeling & $S_{\text {BET }} / \mathrm{m}^{2} \mathrm{~g}^{-1}$ & $V_{\mathrm{p}} / \mathrm{cm}^{3} \mathrm{~g}^{-1}$ & $R_{\text {apd }} / \AA$ & $S_{\mathrm{m}} / \mathrm{m}^{2} \mathrm{~g}^{-1}$ \\
\hline PP.BB & 11.122 & 0.043 & 161.465 & 13.670 \\
PP.BF & 80.806 & 0.270 & 135.520 & 51.962 \\
PP.BL & 83.211 & 0.186 & 97.469 & 51.119 \\
PP.AF & 56.7887 & 0.133 & 93.908 & 10.087 \\
PP.AL & 208.894 & 0.139 & 39.295 & 163.970 \\
\hline
\end{tabular}

$S_{\mathrm{BET}}$, BET specific surface area; $V_{\mathrm{p}}$, pore volume (BJH method); $R_{\text {apd }}$, average pore diameter (BET method); $S_{\mathrm{m}}$, micropore area ( $t$ plot method)

spherical [32]. It is typical of such ash to barely contain an amorphous phase but, in contrast, a well-established crystalline phase. The presence of all the above-mentioned features provides indisputable proof that the raw materials were by-products of coal combustion in CFB boilers.

The morphology of the materials which underwent alkali activation was also subjected to examination (Fig. 4). According to this examination, the morphology of the obtained products markedly differed in comparison with the morphology of the raw materials (Fig. 3). Regardless of the method of synthesis, the products had much more fineness. In the PP.AL sample, there were even some grains whose dimension did not exceed $0.5 \mu \mathrm{m}$. In PP.AF, the average grain diameter was about $1 \mu \mathrm{m}$. There were also clearly visible crystalline phases resembling zeolite materials and amorphous phases which did not undergo crystallization. Similar results were obtained by Franus [33].

Table 5 presents the results of density examinations conducted on the raw materials and on the products of their synthesis. The raw materials had a higher density (about $2.6 \mathrm{~g} \mathrm{~cm}^{-3}$ ) than the products of their synthesis which was due to the hydration processes taking place during the synthesis. The following samples are listed in ascending order, according to their density: PP.AL, PP.BF, PP.BL and PP.AF. It is worth noticing that both samples from CHP plant B had a very similar density. According to these
Fig. 5 Comparison of the results of thermal analysis of the raw materials and the products of their alkali activation. TG, DSC, DTG and mass spectra $(\mathrm{m} / \mathrm{z} 12, \mathrm{~m} / \mathrm{z} 17, \mathrm{~m} / \mathrm{z} 18, \mathrm{~m} / \mathrm{z} 44)$ curves recorded upon heating of the analyzed materials

results, the zeolite synthesis in the sample labeled PP.AL was most effective.

Table 6 presents the results of the examination of porosimetric properties. The characteristics of the porous structure of the PP.BB sample are typical of fly ash from coal combustion in CFB boilers. Sample PP.AL, obtained by using low-temperature synthesis, had the highest value for the BET specific surface area. This value suggests that zeolite material was obtained [34, 35]. That value was approximately $152 \mathrm{~m}^{2} \mathrm{~g}^{-1}$ higher in comparison with the PP.AF sample derived from the same raw material but by means of the fusion method. It was also approximately $127 \mathrm{~m}^{2} \mathrm{~g}^{-1}$ higher than both products obtained from fly ash of CFB boiler from CHP plant B. The average pore diameter in the PP.AL sample was about $40 \AA$, whereas in PP.AF the value of $R_{\text {apd }}$ was more than twice as large and amounted to approximately $94 \AA$. Moreover, there was a significant difference in the micropore area $\left(S_{\mathrm{m}}\right)$ between samples PP.AL and PP.AF derived from the same fly ash from CHP plant A, but by using low-temperature and fusion methods, respectively. The material obtained by means of the low-temperature method had a 16 times larger micropore area than its counterpart obtained by using the fusion method. In contrast, such a difference was not observed between samples PP.BL and PP.BF derived from the same fly ash from CHP plant B and subjected to different methods of alkali activation.

In order to determine all the physical properties and thermal stability of the examined materials, they were also subjected to combined thermal analysis (TG/DSC/QMS) which allows for the thorough qualitative and quantitative assessment of the processes of dehydration and dehydroxylation-very important with regard to zeolite materials. However, applying this particular method to ash of CFB boiler requires both professional skills and experience together with the complementary results of the research which facilitate the proper interpretation of the observed effects (which often have various intensity levels and can occur at different temperature ranges, dependent on the specific ash). The most advisable solution to identify the substrates and products of zeolite synthesis and to determine their characteristics is to compare the modified material with the used raw materials. Due to such comparisons, one may determine (1) the influence of the raw material on the process of zeolite synthesis and (2) the influence of the specific recipe parameters on the properties of the obtained products. 

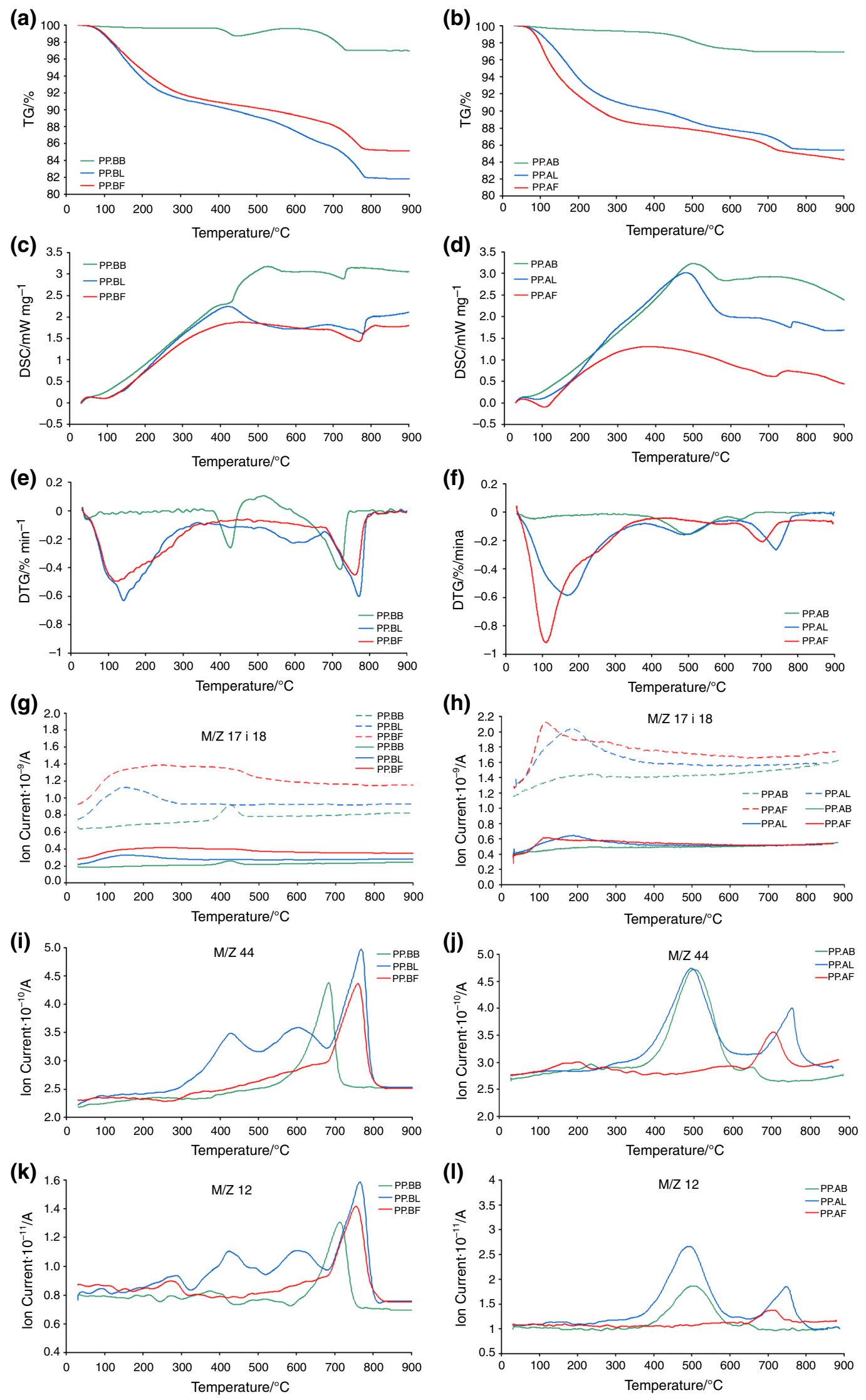
Figure 5 presents the results of TG, DTG, DSC and the composition of the released gas products $\left(\mathrm{CO}_{2}-\mathrm{m} / \mathrm{z} 44\right.$, $\mathrm{C}-\mathrm{m} / \mathrm{z} 12, \mathrm{H}_{2} \mathrm{O}-\mathrm{m} / \mathrm{z} 17$ and $\mathrm{m} / \mathrm{z}$ 18), respectively. All the results are presented on the basis of a temperature increase function of up to $900{ }^{\circ} \mathrm{C}$. The measurement focused on both raw materials and the products of their synthesis by means of low-temperature and fusion methods. The samples of the raw materials (ash in PP.AB and PP.BB) had smaller total mass loss in comparison with the products of their synthesis. The loss on ignition for the PP.AB sample amounted to 3.1 and $3.0 \%$ for the PP.BB sample-there was hardly any difference between the samples in this respect.

According to Fig. 5a, b, e, f and Table 7, the samples of raw materials (PP.AB and PP.BB) on TG and DTG curves between 30 and approximately $390{ }^{\circ} \mathrm{C}$ demonstrated constant and relatively small mass loss. The effects registered on DSC curves (Fig. 5c, d-first endothermic, then exothermic as in Table 8) and the simultaneous increase in the intensity of the released gas products $(\mathrm{m} / \mathrm{z}: 12,17,18$ and 44 , Fig. $5 \mathrm{~g}-1$ ) prove that this loss is connected with moisture evaporation and with the process of oxidation of organic substances (typically taking place in higher temperature ranges).

Only in the PP.BB sample at approximately $385-450{ }^{\circ} \mathrm{C}$ did the endothermic effect occur together with significant mass loss (Table 7; Fig. 5c). This results from the dehydroxylation of the ash, which is proved by the rapid increase in the released gas products derived from $\mathrm{H}_{2} \mathrm{O}$ and by the observed mass loss on the TG curve (Fig. 5a-it is even more evident on the DTG curve Fig. 5e).

In the PP.BB sample and in a high temperature range $\left(670-740{ }^{\circ} \mathrm{C}\right)$, another endothermic effect took place (Fig. 5c; Table 8). It did not occur in the PP.AB sample (Fig. 5d). It resulted from the thermal dissociation of calcium carbonate $\mathrm{CaCO}_{3}$ and was responsible for significant mass loss, amounting to $2.6 \%$ (see TG curve in Fig. 5a, and DTG curve in Fig. 5e; Table 9 where it is even more evident). Thermal dissociation of $\mathrm{CaCO}_{3}$ is proved by the signal enhancement for gas products $\mathrm{m} / \mathrm{z} 12$ and $\mathrm{m} / \mathrm{z} 44$ (C

Table 9 Values of peak extremum on DTG curves for all the examined samples

\begin{tabular}{llll}
\hline Sample & 1 Extremum & 2 Extremum & 3 Extremum \\
\hline PP.AB & 79.2 & 498.4 & 645.7 \\
PP.AL & 167.8 & 489.3 & 740.1 \\
PP.AF & 111.1 & 256 & 702.8 \\
PP.BB & 42.1 & 426.5 & 721.1 \\
PP.BL & 141 & 594.2 & 770.6 \\
PP.BF & 119.1 & - & 760.6 \\
\hline
\end{tabular}

Table 7 Evolution of mass changes along with temperature ranges of the analyzed materials

\begin{tabular}{|c|c|c|c|c|c|c|c|c|c|c|c|c|c|}
\hline \multirow[t]{2}{*}{ Materials } & \multicolumn{3}{|l|}{1 Step } & \multicolumn{3}{|l|}{2 Steps } & \multicolumn{3}{|l|}{3 Steps } & \multicolumn{3}{|l|}{4 Steps } & \multirow{2}{*}{$\begin{array}{l}\text { Loss on } \\
\text { ignition/ } \\
\%\end{array}$} \\
\hline & $\begin{array}{l}\text { Onset/ } \\
{ }^{\circ} \mathrm{C}\end{array}$ & $\begin{array}{l}\text { Endset/ } \\
{ }^{\circ} \mathrm{C}\end{array}$ & $\begin{array}{l}\text { Mass } \\
\text { changes/ } \\
\%\end{array}$ & $\begin{array}{l}\text { Onset/ } \\
{ }^{\circ} \mathrm{C}\end{array}$ & $\begin{array}{l}\text { Endset/ } \\
{ }^{\circ} \mathrm{C}\end{array}$ & $\begin{array}{l}\text { Mass } \\
\text { changes/ } \\
\%\end{array}$ & $\begin{array}{l}\text { Onset/ } \\
{ }^{\circ} \mathrm{C}\end{array}$ & $\begin{array}{l}\text { Endset/ } \\
{ }^{\circ} \mathrm{C}\end{array}$ & $\begin{array}{l}\text { Mass } \\
\text { changes/ } \\
\%\end{array}$ & $\begin{array}{l}\text { Onset/ } \\
{ }^{\circ} \mathrm{C}\end{array}$ & $\begin{array}{l}\text { Endset/ } \\
{ }^{\circ} \mathrm{C}\end{array}$ & $\begin{array}{l}\text { Mass } \\
\text { changes/ } \\
\%\end{array}$ & \\
\hline PP.AB & 30.0 & 380 & -0.8 & 380 & 615 & -2.0 & 615 & 845 & -0.3 & - & - & - & -3.1 \\
\hline PP.AL & 30.0 & 390 & -9.8 & 390 & 620 & -2.5 & 620 & 835 & -2.3 & - & - & - & -14.6 \\
\hline PP.AF & 30.0 & 368 & -11.6 & 368 & 645 & -1.7 & 645 & 745 & -1.5 & 745 & 900 & -0.9 & -15.7 \\
\hline PP.BB & 30.0 & 390 & -0.4 & 390 & 450 & -0.9 & 450 & 740 & +0.9 & 740 & 890 & -2.6 & -3.0 \\
\hline PP.BL & 30.0 & 320 & -8.9 & 320 & 710 & -2.1 & 710 & 680 & -3.1 & 680 & 860 & -4.1 & -18.2 \\
\hline PP.BF & 30.0 & 360 & -8.8 & 360 & 680 & -2.7 & 680 & 870 & -3.4 & - & - & - & -14.9 \\
\hline
\end{tabular}

Table 8 Evolution of DSC changes along with temperature ranges of analyzed materials

\begin{tabular}{|c|c|c|c|c|c|c|c|c|c|c|c|c|}
\hline \multirow[t]{2}{*}{ Materials } & \multicolumn{3}{|c|}{1 Effect endo (due to water) } & \multicolumn{3}{|c|}{2 Effect endo } & \multicolumn{3}{|c|}{3 Effect exo } & \multicolumn{3}{|c|}{4 Effect endo } \\
\hline & $\begin{array}{l}\text { Onset/ } \\
{ }^{\circ} \mathrm{C}\end{array}$ & $\begin{array}{l}\text { Peak max/ } \\
{ }^{\circ} \mathrm{C}\end{array}$ & $\begin{array}{l}\text { Endset/ } \\
{ }^{\circ} \mathrm{C}\end{array}$ & $\begin{array}{l}\text { Onset/ } \\
{ }^{\circ} \mathrm{C}\end{array}$ & $\begin{array}{l}\text { Peak max./ } \\
{ }^{\circ} \mathrm{C}\end{array}$ & $\begin{array}{l}\text { Endset/ } \\
{ }^{\circ} \mathrm{C}\end{array}$ & $\begin{array}{l}\text { Onset/ } \\
{ }^{\circ} \mathrm{C}\end{array}$ & $\begin{array}{l}\text { Peak max./ } \\
{ }^{\circ} \mathrm{C}\end{array}$ & $\begin{array}{l}\text { Endset/ } \\
{ }^{\circ} \mathrm{C}\end{array}$ & $\begin{array}{l}\text { Onset/ } \\
{ }^{\circ} \mathrm{C}\end{array}$ & $\begin{array}{l}\text { Peak max/ } \\
{ }^{\circ} \mathrm{C}\end{array}$ & $\begin{array}{l}\text { Endset/ } \\
{ }^{\circ} \mathrm{C}\end{array}$ \\
\hline PP.AB & 50 & 90.3 & 125 & - & - & - & 125 & 499.1 & 571.7 & - & - & - \\
\hline PP.AL & 50 & 110.2 & 153 & - & - & - & 153 & 481.4 & 568.7 & 686.4 & 756.9 & 767.1 \\
\hline PP.AF & 47.4 & 106.8 & 130 & - & - & - & 130 & 388.0 & 640.8 & 640.8 & 717.6 & 750.3 \\
\hline PP.BB & 39.0 & 100.2 & 120.0 & 385.7 & 430 & 450.3 & 450.3 & 526.6 & 568 & 670 & 725.4 & 740 \\
\hline PP.BL & 50 & 101 & 132 & - & - & - & 144 & 420.2 & 566 & 683.6 & 776.7 & 802 \\
\hline PP.BF & 51 & 103 & 163 & - & - & - & 163 & 449.7 & 685 & 685 & 771 & 811 \\
\hline
\end{tabular}


Fig. 6 Diffractogram of the ash of CFB boiler from CHP plant A subjected to low-temperature synthesis (PP.AL)

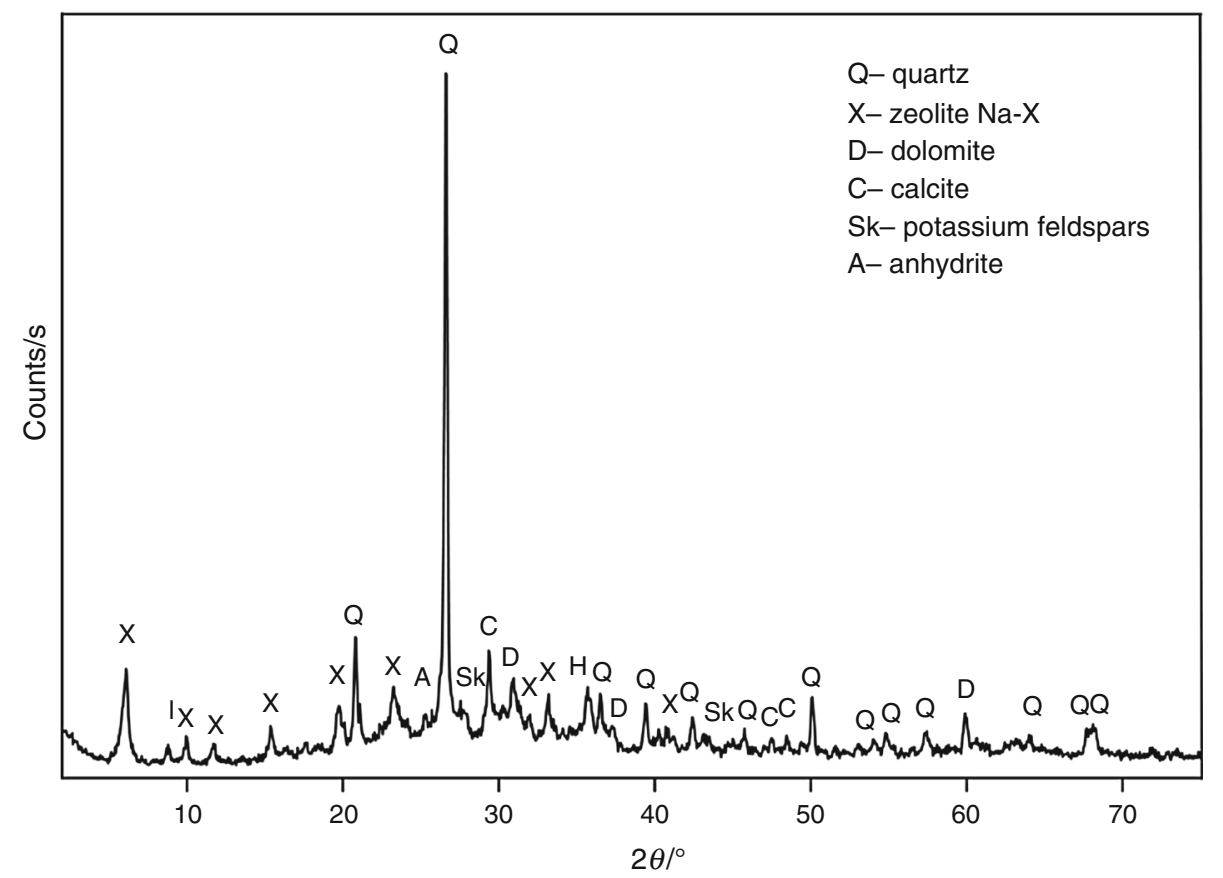

and $\mathrm{CO}_{2}$, respectively; Fig. 5i, k). In the PP.BB sample, there was also a slight mass increase between 450 and $740{ }^{\circ} \mathrm{C}$. Most probably, this results from the oxidation of $\mathrm{Fe}^{2+}$ to $\mathrm{Fe}^{3+}$ stemming from the thermal dissociation of siderite $\mathrm{FeCO}_{3}$. The course of the recorded curves of $\mathrm{C}$ and $\mathrm{CO}_{2}$ seems to support that assumption. However, the above-mentioned effect may as well result from the effects of the thermal dissociation of $\mathrm{CaCO}_{3}$ which occurs within the same temperature range. In the PP.AB sample, such a slight mass increase was not observed and therefore that difference in ash behavior in the elevated temperature range is certainly due to the different contents of siderite $\left(\mathrm{FeCO}_{3}\right)$ in each sample, which was previously determined by means of XRD examination (Fig. 2). According to the analysis of the content of various oxides (Tables 1,2), there was more $\mathrm{Fe}_{2} \mathrm{O}_{3}$ in the PP.AB sample than in the PP.BB. Effects of siderite dissociation only occurred in PP.BB, because the PP.AB sample also contained other iron oxides absent in PP.BB. As a result, despite the fact that the total content of iron oxides was larger in the PP.AB sample, PP.BB contained more siderite and influenced the course of the recorded DSC curves.

Generally, the course of the TG, DTG and DSC curves of the materials obtained from the alkali conversion of fly ash (Fig. 5a-f) does not significantly differ from one another (the main difference lies in the intensity of occurring effects), regardless of the place the ash was derived from and regardless of the applied method of synthesis. However, the TG, DTG and DSC curves of the raw materials and of the products of their synthesis were always markedly different. The mass loss in the case of the latter amounted to $14.6-18.2 \%$ (Fig. 5a, b; Table 7) and was much larger than in the case of the raw materials. Similar values for mass loss were recorded in the investigation carried out by Bukalak et al. [36].

The PP.BL sample had the highest mass loss value. In contrast, the PP.AL sample had the smallest mass loss value. As these samples were obtained by means of the same method of synthesis, such a significant divergence must reflect the difference in the raw material used. With regard to the obtained products of zeolite synthesis, they undergo three stages of mass loss (Fig. 5e, f; Table 9). During the first stage, at the range of $30-390{ }^{\circ} \mathrm{C}$, the process of dehydration takes place. Here, dependent on the examined material, mass loss amounted to between 8.8 and $11.6 \%$. During the second stage, at the range of $390-700{ }^{\circ} \mathrm{C}$, recorded mass loss amounted to $1.7-2.7 \%$, which was due to dehydroxylation. During the third stage, mass loss stems from the thermal dissociation of various carbonates or hydroxides, for example unreacted sodium hydroxide, $\mathrm{NaOH}$.

According to Table 8, DSC curves of the products of low-temperature synthesis (PP.BL and PP.AL samples) reflect the occurrence of strong exothermic effects (at $420{ }^{\circ} \mathrm{C}$ in PP.BL and at $480{ }^{\circ} \mathrm{C}$ in PP.AL) which is due to the combustion of the organic remains present in ash. This is also proved by the significant increase in signals of $\mathrm{m} / \mathrm{z} 12$ and $\mathrm{m} / \mathrm{z} 44$ on the recorded gas product curves. Such effects do not occur in the materials obtained by means of fusion, because their recipe requires thermal treatment at $550{ }^{\circ} \mathrm{C}$. DSC curves reflect some endothermic effects at a temperature range higher than $700{ }^{\circ} \mathrm{C}$ which 
stems from thermal dissociation of carbonates (e.g., $\mathrm{CaCO}_{3}$ ) and is accompanied by significant mass loss which is clearly visible on the TG curve (Fig. 5a, b; Table 7).

The above-mentioned results of the examination seem to prove that the PP.AL sample is a zeolite as it has the smallest density and the highest value for BET specific surface area, which is typical of zeolites. In order to verify this assumption, the PP.AL sample was subjected to XRD phase analysis (Fig. 6), which proved that zeolite $X$ can be obtained from fly ash from CHP plant A by means of lowtemperature synthesis. Apart from zeolite $\mathrm{X}$, the examined sample contained $\mathrm{SiO}_{2}$. This type of zeolite is often synthesized [37-41].

According to the literature [42], the optimal conditions for $\mathrm{X}$ phase synthesis are at $\mathrm{SiO}_{2} / \mathrm{Al}_{2} \mathrm{O}_{3}=1.25$. Despite the fact that $\mathrm{SiO}_{2} / \mathrm{Al}_{2} \mathrm{O}_{3}$ value in sample PP.AB scarcely met that requirement, zeolite $\mathrm{X}$ was obtained. According to the research conducted by Ściubidło et al. [43], X phase may also crystallize from materials whose $\mathrm{SiO}_{2} / \mathrm{Al}_{2} \mathrm{O}_{3}$ ratio is 1.91-2.14. The Na-X zeolite was produced at $\mathrm{SiO}_{2} /$ $\mathrm{Al}_{2} \mathrm{O}_{3} \geq 1.7$ [44]. However, one should notice that the PP.AB sample contained much $(7 \%)$ less $\mathrm{CaO}$ than the PP.BB sample. Because it acts as an inhibitor of zeolite synthesis, its actual amount may significantly influence low-temperature synthesis of Zeolite X.

The results of this research have strong practical applications, because zeolite $\mathrm{X}$ may be extensively used in various technological processes (e.g., catalysis, selective adsorption, particle separation or ion exchange). For instance, it has much better cation exchange capacity (CEC) than the currently used sodalite or analcime $[28,45,46]$.

\section{Conclusions}

A novel aspect of the results presented in the manuscript was the use of ashes from fluidized bed boilers for the synthesis of zeolites. Moreover, the comparison of the efficiency of the formation of the zeolite for different $\mathrm{CaO}$ contents using two methods of synthesis represented an innovative approach.

Fly ash from coal combustion in CFB boilers is not yet to be widely used in industry. We successfully obtained zeolites from such ash by using alkali conversion. According to the XRD examination, fly ash from CHP plant A was indeed turned into zeolite whose BET specific surface area exceeded $200 \mathrm{~m}^{2} \mathrm{~g}^{-1}$ and whose density exceeded $2.365 \mathrm{~g} \mathrm{~cm}^{-3}$. Therefore, the possibility of the industrial application of fly ash from a CFB boiler has been proved.

Also, fly ash from various CHP plants using the same types of CFB boilers may vary in terms of chemical and mineralogical composition. Since we proved that the presence of $\mathrm{Ca}$ in the fly ash severely hinders the zeolite $\mathrm{X}$ synthesis, therefore that crucial factor no longer should be ignored when preparing industrial recipes. Applying the combined thermal analysis allowed to interpret the phenomena, which occurred when samples were heated, and to determine the thermal stability of the examined materials.

Open Access This article is distributed under the terms of the Creative Commons Attribution 4.0 International License (http://creati vecommons.org/licenses/by/4.0/), which permits unrestricted use, distribution, and reproduction in any medium, provided you give appropriate credit to the original author(s) and the source, provide a link to the Creative Commons license, and indicate if changes were made.

\section{References}

1. Piotrowski Z, Uliasz-Boheńczyk A. Możliwości gospodarczego wykorzystania odpadów z kotłów fluidalnych. Gospodarka Surowcami Mineralnymi. 2008;24:73-85.

2. Wesche K. Fly ash in concrete: properties and performance. Report of Technical Committee, 67-FAB RILEM Report 7, 1991.

3. Jarema-Suchorowska S, Kuczak B. Właściwości popiołów z kotłów fluidalnych $\mathrm{w}$ energetyce $\mathrm{w}$ aspekcie warunków gospodarczego wykorzystania tych odpadów. Energetyka. 2010;1:39-43.

4. Chica A. Zeolites: promised materials for the sustainable production of hydrogen. ISRN Chem Eng. 2013; doi:10.1155/2013/ 907425 .

5. Armbruster T, Gunter ME. Crystal structures of natural zeolites, natural zeolites: occurrence, properties, application. In: Blish DL, Ming DW, editors. Reviews in mineralogy and geochemistry, vol. 45. Washington: Mineralogical Society of America; 2001. p. 1-67.

6. Zhdanov SP, Khnoshchev SS, Feoktistova NN. Synthetic zeolite. New York: Gordon and Breach Science Publishers; 1990.

7. Ríos CA, Williams CD, Fullen MA. Nucleation and growth history of zeolite LTA synthesized from kaolinite by two different methods. Appl Clay Sci. 2009;42:446-54.

8. Barth-Wirsching U, Holler H, Klammer D, Konrad B. Synthetic zeolites formed from expanded perlite: type, formation conditions and properties. Mineral Petrol. 1993;48:275-94.

9. Franus W. Characterization of X-type zeolite prepared from coal fly ash. Pol J Environ Stud. 2012;21:337-43.

10. Chigondo M, Guyo U, Shumba M, Chigondo F, Nyamunda B, Moyo M, Nharingo T. Synthesis and characterisation of zeolites from coal fly ash (CFA). Eng Sci Technol Int J (ESTIJ). 2013;3:714-8.

11. Georgiev D, Bogdanom B, Angelova K, Markovska I, Hristov Y. Synthetic zeolites-structure, classification, current trends in Zeolite synthesis. International science conference. Economics and society development on the base of knowledge; 4-5 Jun 2009. Stara Zagora; Bułgaria. http://www.sustz.com/Proceed ing09/Papers/Technical\%20studies/D_GEORGIEV.pdf. Accessed 7 Dec 2015.

12. Majchrzak-Kucęba I, Nowak W. A thermogravimetric study of the adsorption of $\mathrm{CO}_{2}$ on zeolites synthesized from fly ash. Thermochim Acta. 2005;437:67-74.

13. Grela A, Hebda M, Łach M, Mikuła J. Thermal behavior and physical characteristics of synthetic zeolite from CFB-coal fly ash. Microporous Mesoporous Mater. 2016;220:155-62.

14. Trník A, Scheinherrova L, Medved' I, Cerny R. Simultaneous DSC and TG analysis of high-performance concrete containing natural zeolite as a supplementary cementitious material. J Therm Anal Calorim. 2015;121:67-73. 
15. Moutsatsou A, Karakasi O, Koukouzas N, Itskos G, Vasilatos Ch. Synthesis of zeolitic materials utilizing CFB-derived coal fly ash as a raw material. 2009. http://www.academia.edu/164416.

16. KoukouzasN, Vasilatos Ch, Itskos G, Moutsatsou A. Characterization of CFB-coal fly ash zeolitic materials and their potential use in wastewater treatment, 2009 World of Coal Ash (WOCA) conference, May 4-7, in Lexington, USA. 2009. http://www. flyash.info/2009/088-itskos2009.pdf.

17. Giergiczny Z. Rola popiołów lotnych wapniowych i krzemionkowych w kształtowaniu właściwości współczesnych spoiw budowlanych i tworzyw cementowych. Monografia 325, seria Inżynieria Lądowa, Wydawnictwo Politechniki Krakowskiej, Kraków, 2006.

18. Suchecki TT. Zeolity z popiołów lotnych : otrzymywanie i aplikacje w inżynierii środowiska. Wroclaw: Zakład Narodowy im. Ossolińskich; 2005.

19. Pal P, Das JK, Das N, Bandyopadhyay S. Synthesis of NaP zeolite at room temperature and short crystallization time by sonochemical method. Ultrason Sonochem. 2013;20:314-21.

20. Zhang X, Tang D, Jiang G. Synthesis of zeolite NaA at room temperature: the effect of synthesis parameters on crystal size and its size distribution. Adv Powder Technol. 2014;24:689-96.

21. Zhang X, Tong DQ, Zhao JJ, Li XY. Synthesis of NaX zeolite at room temperature and its characterization. Mater Lett. 2013; 104:80-3.

22. Zhang X, Tong D, Jia W, Tang D, Li X, Yang R. Studies on room-temperature synthesis of zeolite NaA. Mater Res Bull. 2014;52:96-102.

23. Hebda M, Laska M, Szechyńska-Hebda M. Application of a device used for observation of controlled thermal processes in a furnace. J Therm Anal Calorim. 2013;114:1099-109.

24. Hebda M, Gądek S, Skałoń M, Kazior J. Effect of mechanical alloying and annealing on the sintering behaviour of AstaloyCrL powders with $\mathrm{SiC}$ and carbon addition. J Therm Anal Calorim. 2013;113:395-403.

25. Szechyńska-Hebda M, Hebda M, Mierzwiński D, Kuczyńska P, Mirek M, Wędzony M, van Lammeren A, Karpiński S. Effect of cold-induced changes in physical and chemical leaf properties on the resistance of winter triticale ( $\times$ Triticosecale) to the fungal pathogen Microdochium nivale. Plant Pathol. 2013;62:867-78.

26. Giergiczny Z. The hydraulic activity of high calcium fly ASH. J Therm Anal Calorim. 2006;83:227-32.

27. Murayama N, Yamamoto H, Shibata J. Mechanism of zeolite synthesis from coal fly ash by alkali hydrothermal reaction. Int $\mathrm{J}$ Miner Process. 2002;64:1-17.

28. Hollman G, Steenbruggen G, Janssen-Jurkovicova M. A two-step process for the synthesis of zeolites from coal fly ash. Fuel. 1999;78:1225-30.

29. Bukalak D, Majchrzak-Kucęba I, Nowak W. Wpływ zawartości $\mathrm{Si}$ i Al w popiele lotnym na tworzenie się frakcji.
30. Inada M, Eguchi Y, Enomoto N, Hojo J. Synthesis of zeolite from coal fly ashes with different silica-alumina composition. Fuel. 2005;84:299-304.

31. Sun Y, Fu K, Zhu H, Zhu T. Silica-alumina molar ratio and some factors effect on the synthesis of zeolites from fly ash. J Coal Sci Eng. 2009;15:430-3.

32. Iwanek P, Jelonek I, Mirkowski Z. Wstępne badania popiołów z kotła fluidalnego w aspekcie ich zagospodarowania. Gospodarka Surowcami Mineralnymi. 2008;24:91-104.

33. Franus W. Materiał zeolitowy typu X otrzymany z popiołu lotnego w wyniku syntezy hydrotermalnej i niskotemperaturowej. Budownictwo i Architektura. 2010;7:25-34.

34. Ziółek M, Nowak I. Heterogeneous catalysis. Selected issues. Poznań: Wydawnictwo Naukowe UAM; 1999.

35. Payra P, Dutta PK. Zeolites: a primer. In: Auerbach SM, Carrado KA, Dutta PK, editors. Handbook of zeolite science and technology. New York: Marcel Dekker; 2003.

36. Bukalak D, Majchrzak-Kucęba I, Nowak W. Assessment of the sorption capacity and regeneration of carbon dioxide sorbents using thermogravimetric methods. J Therm Anal Calorim. 2013;113:157-60. doi:10.1007/s10973-013-3052-0.

37. Querol X, Moreno N, Umaňa JC, Alastuey A, Hernăndez E, López-Soler A, Plana F. Synthesis zeolites from coal fly ash: an overview. Int J Coal Geol. 2002;50:413-23.

38. Tanaka H, Furusawa S, Hino R. Synthesis, Characterization and formation process of $\mathrm{Na}-\mathrm{X}$ zeolite from coal fly ash. J Mater Synth Process. 2002;10:143-8.

39. Tanaka H, Matsumura S, Furusawa S, Hino R. Conversion of coal fly ash to Na-X zeolites. J Mater Sci Lett. 2003;22:323-5.

40. Tanaka H, Matsumura S, Hino R. Formation process of Na-X zeolites from coal fly ash. J Mater Sci. 2004;39:1677-82.

41. Kalvachev Y, Zgureva D, Boycheva S, Barbov B, Petrova N. Synthesis of carbon dioxide adsorbents by zeolitization of fly ash. J Therm Anal Calorim. 2015; doi:10.1007/s10973-015-5148-1.

42. Shigemoto N, Hayashi H, Miyaura K. Selective formation of Na$\mathrm{X}$ zeolite from coal fly ash by fusion with sodium hydroxide prior to hydrothermal reaction. J Mater Sci. 1993;28:4781-6.

43. Ściubidło A, Majchrzak-Kucęba I, Nowak W. Characterization of zeolites from polish fly ashes. 26th annual international Pittsburgh coal conference; 2009.

44. Tanaka H, Eguchi H, Fujimoto S, Hino R. Two-step process for synthesis of a single phase Na-A zeolite from coal fly ash by dialysis. Fuel. 2006;85:1329-34.

45. Querol X, Umana JC, Plana F, Alastuey A, Lopez-Soler A, Medinaceli A, Valero A, Domingp MJ, Garcia-Rojo E. Thesis of zeolites from fly ash at pilot plant scale. Examples of potential applications. Fuel. 2001;80:857-65.

46. Adamczyk Z, Białecka B. Hydrothermal synthesis of zeolites from Polish coal fly ash. Pol J Environ Stud. 2005;6:713-9. 